\title{
Threats and Opportunities to Major Rift Valley Lakes Wetlands of Ethiopia
}

\author{
Teklu Gebretsadik* and Kassahun Mereke \\ Hawassa Agricultural Research center, South Agricultural Research Institute, Ethiopia
}

Submission: June 16, 2017; Published: July 28, 2017

"Corresponding author: Teklu Gebretsadik, Hawassa Agricultural Research center, South Agricultural Research Institute, Hawassa, Ethiopia, Email: gebretsadikteklu@yahoo.com

\begin{abstract}
Rapid declines threaten the persistence of many rift valley lake wastelands. Few populations recover rapidly, most exhibit little or no change in abundance up to recent years after a collapse. Reductions in fishing pressure, although clearly necessary for population recovery, are often insufficient. Persistence and recovery are also influenced by life history, habitat alteration, changes to species assemblages, genetic responses to exploitation, and reductions in population growth attributable to the wetland effect. Unprecedented reductions in abundance and surprisingly low rates of recovery draw attention to scientists' limited understanding of how fish behavior, habitat, ecology, and evolution affect population growth at low abundance. Failure to prevent population collapses and to take the conservation biology of marine resources seriously will ensure that many severely depleted rift valley species remain wetlands, ecological and numerical shadows in the ecosystems that they once dominated.

Keywords: Rift valley lake; Conservation biology; Lake wetlands; Threats and opportunities; Ethiopia
\end{abstract}

\section{Introduction}

Wetlands are among the most threatened habitats globally, and it is estimated that since 1900 more than half of the world's wetlands have been destroyed and lost to other land uses. Despite various forms of international and national legislation ratifying their protection [1], wetlands continue to be affected by human activities.

The economic benefits and services provided by wetland ecosystems are frequently overlooked by

\section{Governments}

2. Developers

3. Private industry and other land users resulting in distorted decisions.

Ethiopia is often referred to as the water tower of Africa creating an extensive wetland system throughout the country. The Ethiopian Rift system extends from the Kenyan border up to the Red Sea and is divided into four sub-systems.
A. Lake Rudolf
B. Chew Bahir

\section{The Main Ethiopian Rift (MER) and \\ D. The Afar}

Some of the lakes are used for irrigation, water supply, soda abstraction, commercial fish farming [2,3], and recreation and support a wide variety of endemic birds and wild animals.

\section{Objective}

To assess the major rift valley lakes wetlands and describe the future treats for sustainability

\section{Wetland concepts}

While water is a major factor of wetland definition soils, vegetation and animal life also contribute to their unique characteristics. The definition that is used by the Ramsar Convention is as follows [4], "areas of marsh, fen, peatland or water, whether natural or artificial, permanent or temporary, with water that is static or flowing, fresh, brackish or salt, including areas of marine water the depth of which at low tide does not exceed six meters" [5]. The wide diversity of landscapes of the Ethiopian Rift Valley (ERV) and ecosystems comprise extensive biodiversity-rich wetlands. At the same time the ERV 
is one of the environmentally very vulnerable areas in Ethiopia. There is a clear decrease of the water resources. Lake levels have been lowered and wetlands have been deteriorated.

\section{Major Lakes and Associated Wetlands}

\section{Lake abe}

Description: Lake Abe is one of several chain of saline lakes into which the Awash River drains. It is located on the western border of Djibouti at an elevation of $240 \mathrm{~m}$ a.s.l. Estimates of its present extent are not well documented but clearly show that the original surface has diminished extensively.

Threats: Arid climatic conditions coupled with unrestricted use of its waters can lead to its demise. At present, the water appears to be restricted to local use where the main activity is watering domestic stock and small-scale irrigation. Heavy water abstraction of the Awash upstream is a potential risk that could put the Lake at risk for the future [6,7].

\section{Lake beseka}

According to Tenalem, Lake Beseka is expanding drastically as a result of Enhancement of recent groundwater recharge caused by very high infiltration from nearby over-irrigated fields and Transmission losses in high rise of the Awash River affected by upstream damming [8-10].

\section{Lake ziway}

5.3.1.Description: Lake Ziway is one of the largest freshwater Rift Valley Lakes of the country. It has an average altitude of $1850 \mathrm{~m}$ a.s.l, a surface area of $434 \mathrm{~km} 2$ and an average depth of 4 meters. This lake is known mostly for its large size, fisheries and islands [11-13]. The lake is fed by Meki and Katar rivers from the north and northeast respectively. It is drained by the Bulbula River which enters Lake Abijatta. Besides the thriving fisheries, the lake supplies water for the town, irrigation for nearby floriculture farms.

Threats: Abraham stated that, natural causes including climate change could alter the ecosystem ending in undesirable long-term effects. Anthropogenic causes stem from deforestation in the upper watersheds, loss of Acacia woodlands, lake shore farming and destruction of buffer zones. Other critical threats include siltation, water abstraction, overfishing and release of pollutants into the lake system [14,15] (Figure 1-3).
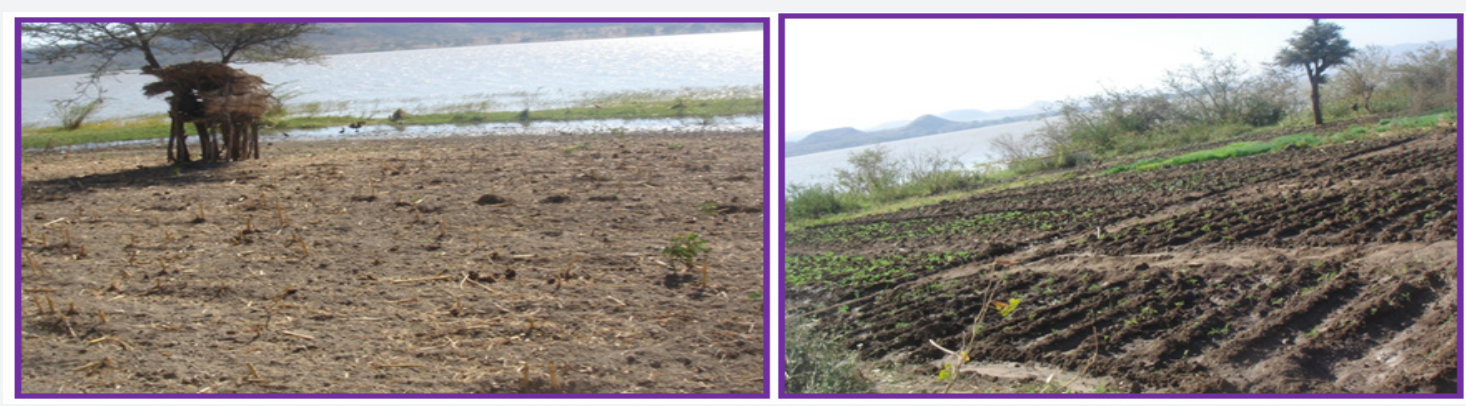

Figure 1: Wetland vegetation in Ziwaylake is getting depleted due to shoreline farming.
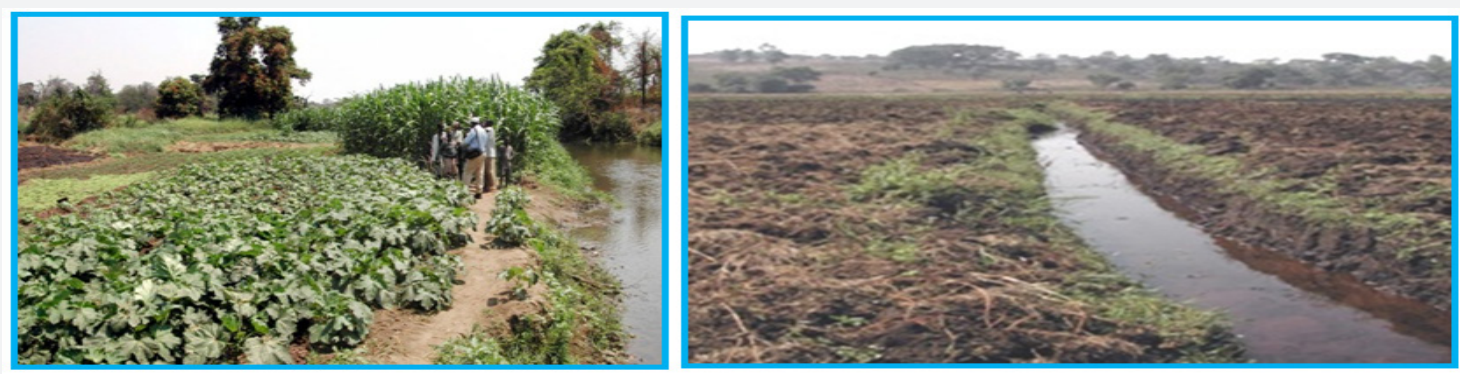

Figure 2: Water abstraction from Lake Ziway for irrigation.

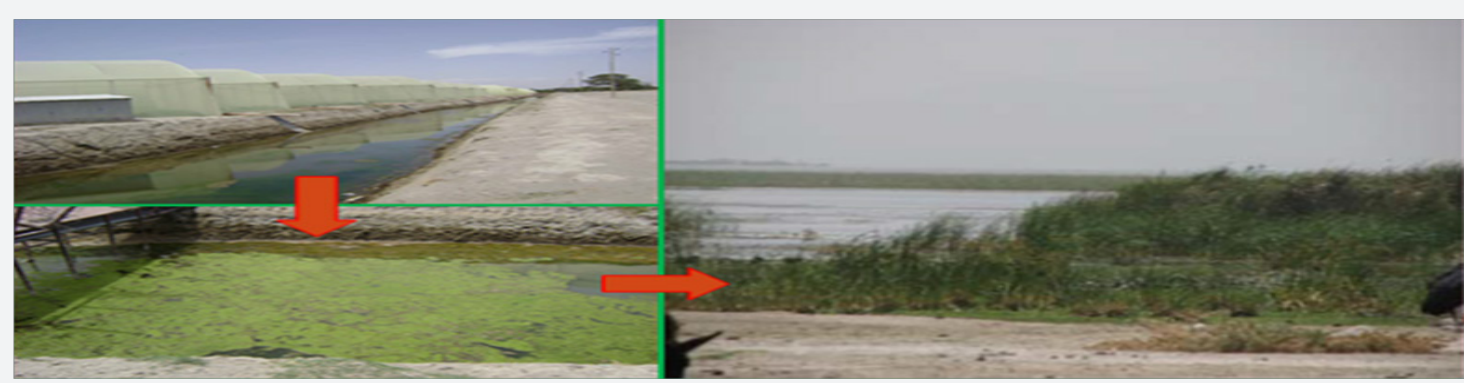

Figure 3: Direct disposal of untreated effluents into lake ziway. 


\section{Lake langano}

Description: A high percentage of its water comes from precipitation. Hora Kello forms its only outlet flowing into Lake Abijatta. Its average depth is around 20 meters. The sandy beaches on the western shores attract tourists in high numbers [16].

Threats: The area in general is located in a dry and water scarce zone. Tourism is a high profile industry at this lake and its effects are not clearly known [17]. Without a control system in place, increasing resorts and growing numbers of tourists can have negative effects in the long term.

\section{Lake abijatta}

Description: Abijatta is a shallow terminal lake with a surface area of $176 \mathrm{~km} 2$ with an altitude of $1582 \mathrm{~m}$ a.s.l. It has a maximum depth of 14 meters and an average of 7.6 meters.
According to Legesse et al. the catchment drained by the lake is around $1630 \mathrm{~km} 2$ and it is affected by the inflows of water from Ziway and Langano [18-20].

\section{Threats}

The main threats that could negatively affect the lake include

1) Overgrazing

2) Devegetation of the upper catchment of the lake

3) Abstraction of the lake water for soda ash mining,

4) Upstream water abstraction especially from the Bulbula River and

5) The lake may dry up at end due to fall of its water table. The lake is located in a water deficit spot of the country and as a result also has natural problems (Figure 4-6).

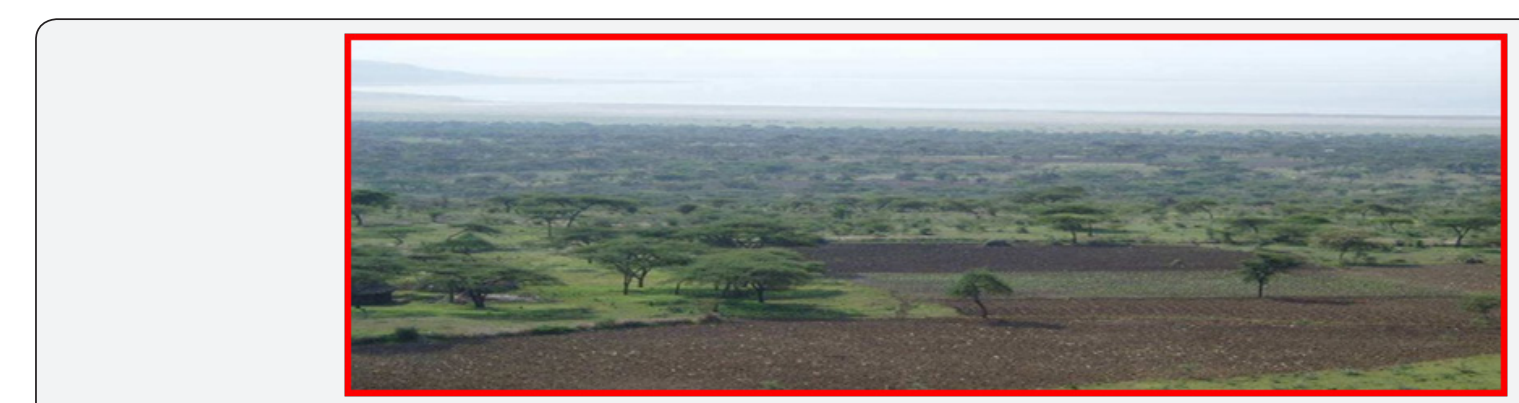

Figure 4: De-vegetation of upper watershed of Lake Abijata.

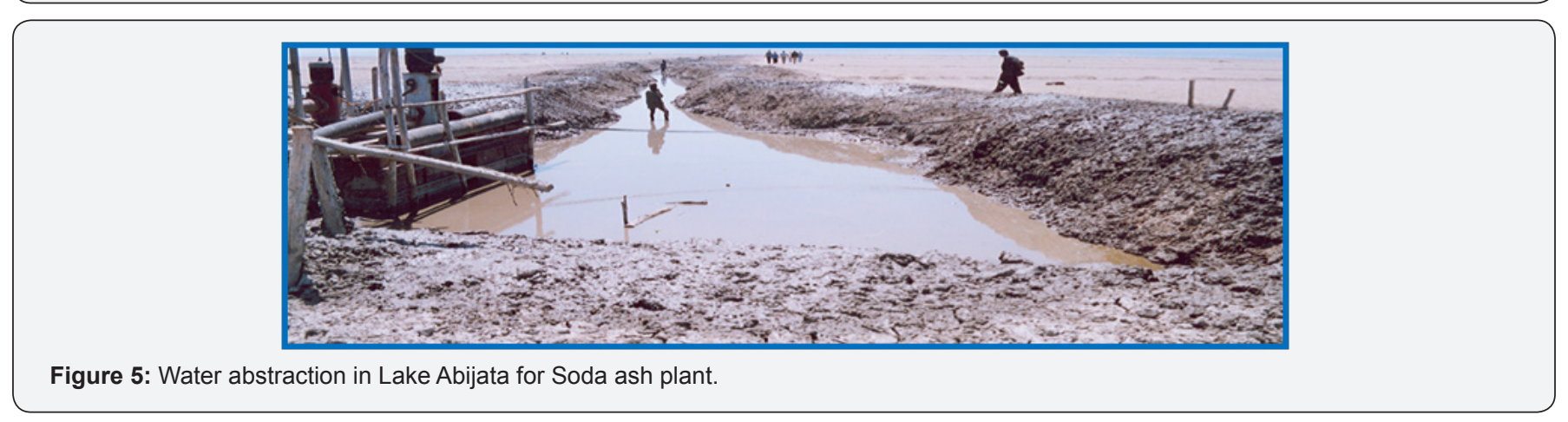

Figure 5: Water abstraction in Lake Abijata for Soda ash plant.
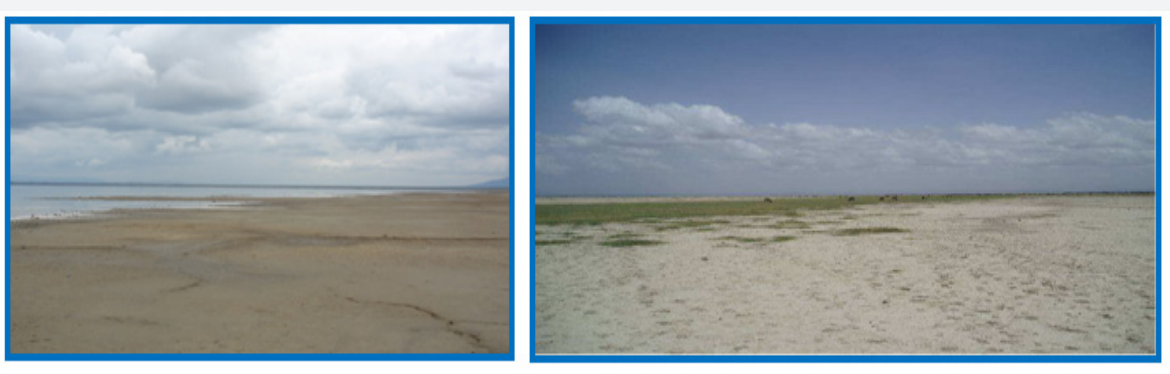

Figure 6: Falling water table of Lake Abijata.

\section{Lake shala}

Description: Lake Shalla is a deep saline crater lake with a surface area of $329 \mathrm{~km} 2$ at an altitude of $1570 \mathrm{~m}$ a.s.l. It has a maximum depth of 266 meters and a mean depth of 87 meters $[21,22]$. Shalla has an independent sub-basin of its own and drains a catchment of $3920 \mathrm{~km} 2$. A threat to this lake is not 
reported yet, because the lake is entirely protected, together with an area of peripheral land, in the Abiyata-Shala National Park.

\section{Lake awassa}

Description: It is found in the Central Rift Valley system with altitudes ranging from $1670-2000 \mathrm{~m}$ a.s.l. With total area of
$90 \mathrm{~km} 2$, it is the smallest lake in the Rift Valley system. Desta stated that, Awassa Lake receives its recharge from groundwater through precipitation [23-25]. Besides, the Wondo Genet watershed is an important source of water through the wetlands of Shallo swamp. The lake provides suitable habitat and breeding ground for various fish species (Figure 7).
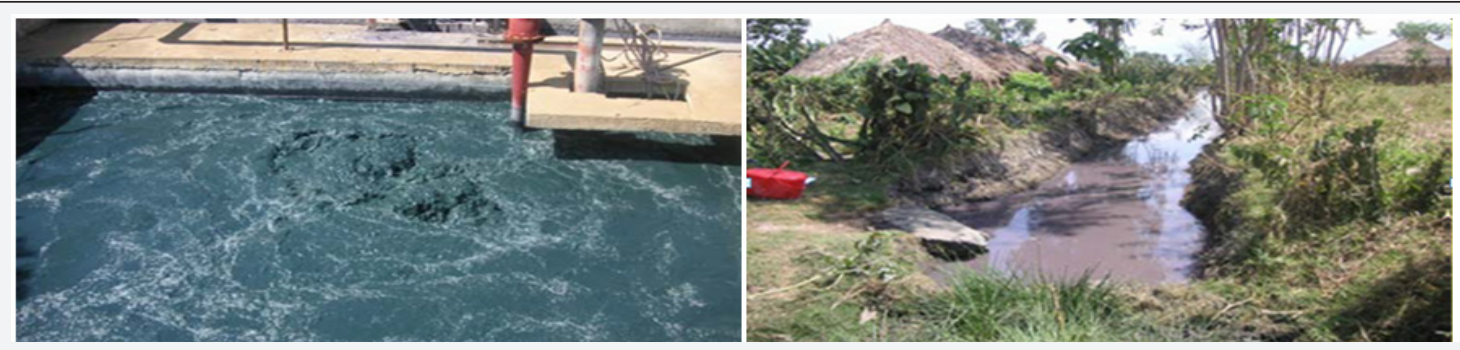

Figure 7: Effluent discharge from Awassa Textile Factory to Lake Awassa.

\section{Summary of Threats to Rift Valley Lakes Wetlands}

\section{Draining for agriculture}

Long term draining interferes with the ecological recovery of the wetland system and will fasten its drying up. In Afar regional state, many areas of wetland have been lost during 1960's due to the increase of irrigation practice in the area [26]. As a result the state has lost many of wetlands from the area.

\section{Over grazing}

Wetlands are often a last destination for pastoralists during the dry season. Over grazing is a threat when year round grazing excludes ecological recovery period of the wetland which implies loss of biodiversity [27]. Compaction of the wetland also have impact on the infiltration capacity of the soil hence affecting the hydrological system and balance of the wetland itself.

\section{Over exploitation of wetland resources}

Over-exploitation of wetland resources is now a major threat in several wetland areas of Ethiopia. A good example of over-exploitation is the fishery resource from Lake Ziway in the Oromia Regional State [28]. Excessive exploitation of resources can also lead in some cases to a direct collapse of the wetland itself. A good example for this scenario is the collapse of Lake Alemaya. An excessive water withdrawal was believed to be a major cause for the collapse of the lake even though siltation also has played its part.

\section{Deforestation, siltation and soil erosion}

The accumulation of silt complete change in the ecosystem biodiversity alteration, decreases in the water holding capacity and in the worst case the collapse of the wetland itself. Introduction of nonnative plants to the wetland [29], removal of buffering vegetation and upland forest degradation are the main causes for the loss of vegetation.

\section{Urbanization and industrialization}

Due to the abundance of natural resources many urban centers are located near wetlands. Although wetlands are capable of absorbing pollutants from the surface water, there is a limit to their capacity to do so the primary pollutants; sediment, fertilizer, human sewage, animal waste, pesticides, heavy metals.

\section{Overfishing}

Overfishing may result in the loss of some fish species. On Lake Chamo, the 'gancho' net has caused the rapid depletion of Nile perch stocks. Some $70 \%$ of the fish landed from the Rift Valley Lakes comes from Lake Ziway alone, suggesting excessive fishing pressure [30].

\section{Demographic pressure}

According to Kassahun, 6 million people in the Abaya, Chamo, Awassa and Chew-Bahircatchments, population density of more than 160 people/km2

\section{Introduction of floriculture industries}

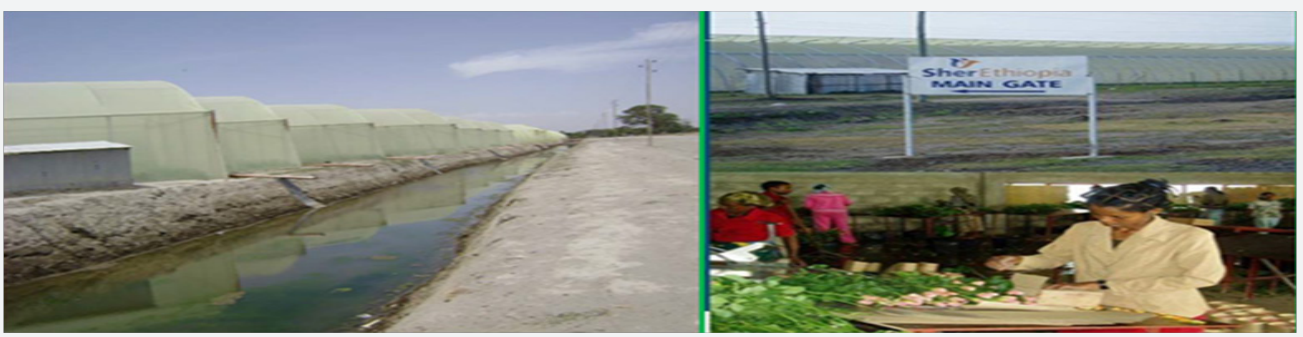

Figure 8: Introduction of floriculture industries at the shoreline of lake ziway. 
The rift valley in Ethiopia is a hot spot for flower production. Water availability and transport links provide suitable conditions for this industry. One large company Sher Ethiopia now occupies about 300 hectares in Ziway (Figure 8).

\section{Climate change}

Wetland ecosystems are threatened by the impacts of climate change. Globally, the impacts of climate change on freshwater systems are expected to outweigh the benefits. Climate change is increasing uncertainty in water management and making it difficult to close the gap between water demand and supply [3133].

\section{Opportunities to Rift Valley Lakes Wetlands}

Different actors need to be sensitized, to accept the existence of problems and to show a willingness to start working on the wetland.

A. It is hoped that new water and environmental policies can reverse deleterious existing trends.

B. Every part of society should work hard to enforce laws and bring about desired changes.

C. Stringent laws must be enacted and enforced to save the forest cover elsewhere in the area.

D. Sound strategies and projects need to be designed and implemented to rehabilitate degraded lands.

E. The amount and type of agricultural chemicals used in the wetland's catchment and leached into the wetlands has to be studied.

F. Empowering local communities to conserve and protect their wetlands

\section{Conclusion}

The threats facing the wetlands in the Main Ethiopian Rift show that the bases of the degradation of the wetlands are indeed human activities.

1. Economic policies and strategies that decrease the food security of local communities should be avoided.

2. The understanding of possible solutions to wetland degradation has to be reviewed encouraging effective local strategies.

3. Building partnership is essential to mobilize existing knowledge on wetlands, existing capacity and funding mechanisms at all levels.

4. Finally, it is useful to remain realistic about the feasibility of policy and strategy, implementation and law enforcement.

\section{References}

1. Bromley D (1991) Environment and Economy: Property Rights and Public Policy. Basil Blackwell, UK.
2. Thorne-Miller B, Catena J (1991) The Living Ocean, Understanding and Protecting Marine Biodiversity. Island Press, New York, USA.

3. Stewart JE (1991) Introductions as factors in diseases of fish and aquatic invertebrates. Can J Fish Aquat Sci 48(Suppl 1): 110-117.

4. Smith T (1994) Scaling Fisheries, Cambridge: Cambridge University Press, India.

5. MacLennan DN (1995) Technology in Capture Fisheries. Paper presented at the Government of Japan/FAO International Conference on Sustainable Contribution of Fisheries to Food Security, Kyoto, Japan, pp. 4-9.

6. (1995) Review of the state of World Aquaculture. FAO Fisheries Circular No. 886 Rev 1, Rome, Italy.

7. Mace PM (1997) Developing and sustaining world fisheries resources: the state of the science and management. In: Hancock DA, et al. (Eds.), Second World Fisheries Congress. CSIRO Publishing, Collingwood, Australia, pp. 98-102.

8. Pauly D, Silvestre G, Smith IR (1989) on development, fisheries and dynamite: a brief review of tropical fisheries management. Natural Resource Modeling 3(3): 307-329.

9. Rodriguez MA, Lewis WM (1997) Structure of fish assemblages along environmental gradients in floodplain lakes of the Orinoco River. Ecological Monographs 67: 109-128.

10. Elinor O, Joanna B, Christopher BF, Richard BN, David P (1999) Revisiting the Commons: Local Lessons, Global Challenges. Science 284(5412): 278-282.

11. FAO (1999) The State of World Fisheries and Aquaculture 1998. FAO, Rome, Italy.

12. FAO (2000) The State of World Fisheries and Aquaculture 2000. FAO, Rome, Italy.

13. Elias Dadebo (2000) Reproductive biology and feeding habits of the Cat fish Claris gariepinus in Lake Hawassa. SINET: Eth JSci 23(2): 231-246.

14. Naylor RL, Goldberg RJ, Primavera JH, Kautsky N, Beveridge MC, et al. (2000) Effect of aquaculture on world fish supplies. Nature, 405(6790): 1017-1024.

15. Witherell D, Pautzke C, Fluharty D (2000) An ecosystem-based approach for Alaska groundfish fisheries. IC Journal of Marine Science 57: 771-777.

16. Hamre J (2003) Capelin and herring as key species for the yield of north-east Artic cod. Results from multispecies runs. Sci Mar 67(suppl 1): $315-323$

17. Davis L, Thoms MC, Fellows CS, Bunn SE (2002) Physicaland ecological associations in drylandrefugia: waterholes of the Cooper Creek, Australia. International Association of Hydrological Sciences 276: 7784.

18. Stokstad E (2006) Global loss of biodiversity harming ocean bounty. Science 314(5800): 745.

19. Rebufat F (2007) The old man and the sea: a necessary change of course. Research EU pp. 5-6.

20. FAO Fisheries and Aquaculture Department (2007) The State of World Fisheries and Aquaculture 2006, Food and Agriculture Organization of the United Nations, Rome, Italy.

21. Morris JAJ, Akins JL (2009) Feeding ecology of invasive lionfish (Pteroisvolitans) in the Bahamian Archipelago. Environmental Biology of Fishes 86: 389-398.

22. Fridley JD, Bromberg KD, Bertness MD (2005) Insights into biotic interactions from Bruno studies of species invasions. In: Sax DF, Stachowicz JJ, Gaines SD, (Eds.), Species invasions: insights into 
ecology, evolution, and biogeography. Sunderland Sinauer Associates Inc, USA, pp. 13-40.

23. Green SJ, Akins JL, Côté IM (2011) Foraging behaviour and prey consumption in the Indo-Pacific lionfish on Bahamian coral reefs. Marine Ecology Progress Series 433: 159-167.

24. Clavero M, Garci'a-Berthou E (2006) Homogenization dynamics and introduction routes of invasive freshwater fish in the Iberian Peninsula Ecol Appl 16(6): 2313-2324.

25. Marchetti MP, Moyle PB, Levine R (2004) Alien fishes in California Watersheds: characteristics of successful and failed invaders. Ecological Applications 14: 587-596.

26. Brylińska M (2000) Rybysłodkowodne Polski. The freshwater fishes of Poland. PWN, Warszawa, Poland.

27. Riberio F, Elvira B, Collares-Pereira MJ, Moyle PB (2008) Life-history trans of non-native fishes in Iberian watersheds (czeck republic book) across several invasion stages: a first approach. Biol Invasions 10: 89102.

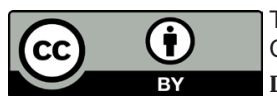

This work is licensed under Creative Commons Attribution 4.0 License

DOI: $10.19080 /$ ARTOAJ.2017.09.555751.
28. Genovesi P, Shine C (2003) European strategy and invasive alien species. czeck book, Final vers, Strasbourg, France.

29. Kostrzewa J, Grabowski M (2003) Oportunistic feeding strategy as factor promoting the expansion of racer go by (NeogobiusgymnotrachelusKessler, 1857) in the Vistula basin. Lauterbornia 48: 91-100.

30. Kownacki A (2004) Branchinecta palludosa Müller OF 1788. In: Głowaciński Z, Nowacki J (Eds.), Polish Red Data Book of AnimalsInvertebrates. IOP PAN - Kraków, AR- Poznań: 35-36.

31. Hermoso V, Clavero M, Blanco-Garrido F, Prenda J (2011) Invasive species and habitat degradation in Iberian streams: an analysis of their role in freshwater fish diversity loss. Ecol Appl 21(1): 175-188.

32. King RB, Ray JM, Stanford KM (2006) Gorging on gobies: beneficial effects of alien prey on a threatened vertebrate. Can J Zool 84(1): 108115.

33. Roessig JM, Woodley CM, Cech JJ, Hansen LJ (2004) Effects of global climate change on marine and estuarine fishes and fisheries. Reviews in Fish Biology and Fisheries 14(2): 251-275.

\section{Your next submission with Juniper Publishers will reach you the below assets}

- Quality Editorial service

- Swift Peer Review

- Reprints availability

- E-prints Service

- Manuscript Podcast for convenient understanding

- Global attainment for your research

- Manuscript accessibility in different formats

( Pdf, E-pub, Full Text, Audio)

- Unceasing customer service

Track the below URL for one-step submission https://juniperpublishers.com/online-submission.php 